Драган Б. Бабић

Универзитет у Новом Саду

Филозофски факултет

Студент докторских студија

draganb.com@gmail.com
UDK 821.111.09-31 Woolf V. DOI: 10.19090/zjik.2019.195-209 оригинални научни рад

\title{
ПРЕДВИЪАЊЕ И ЕФЕКАТ ПРВОГ СВЕТСКОГ РАТА У РОМАНИМА ИЗЛЕТ НА ПУЧИНУ И ЩЕЈКОБОВА СОБА ВИРЏИНИЈЕ ВУЛФ ${ }^{1}$
}

САЖЕТАК: При читању и истраживању дела Вирџиније Вулф, већина истраживача и читалаца се задржава на неколицини наслова: романима Госпођа Даловеј, Ка светионику и Таласи, те обимним есејистичким делима Сопствена соба и Три гвинеје. Док је тај поступак услед квалитета тих наслова апсолутно разумљив, он није потпуно праведан. Улазећи дубље у њен рад, можемо открити и друге наслове вредне пажње, као што су њен први роман Излет на пучину, те трећи, Цејкобова соба. Значај ових дела није само у њиховом антиципирајућем фактору - јер они заиста антиципирају Госnођу Даловеј, Таласе и друга прозна дела која је ауторка писала након њих - већ и у начину на који се опходе према теми Првог светског рата. Наиме, иако је овај догађај изразито битан у животу и раду ауторке, он не заузима централно место у овим романима. Они су објављени током и након рата - 1915, односно 1922. године - и садрже јунаке који учествују у рату и погођени су њиме, али се ка њима не односе на очигледан и отворен начин. Уместо тога, они наговештавају рат и његове последице употребом више различитих приповедних и стилских техника, а управо ће те технике, као и њихов значај, бити у фокусу овог рада.

Кључне речи: Вирџинија Вулф, Излет на пучину, Цејкобова соба, Први светски рат, антиципација

${ }^{1}$ Рад је настао као део истраживања приликом израде докторске дисертације под насловом „Тематизација Првог светског рата у српској и англоамеричкој прози од 1914. до 1940: компаративна анализа““ и под менторством проф. др Владимира Гвоздена на Филозофском факултету у Новом Саду. 
Одлучивши се да се опроба у књижевности не само као читалац, критичар и есејиста, већ и као прозни писац, Вирџинија Вулф 1907. почиње да скупља грађу за свој први роман, мислећи да ће писање дела о путу протагонисткиње Рејчел Винрејс бродом „Еуфросина“ бити кратак, учинковит и једноставан посао. Међутим, то искуство било је потпуно супротно, а овај рукопис јој доноси огроман посао - и током писања и у процесу преправљања - и велик стрес. Тај притисак узнемирава њену психу и појачава њену нестабилност, и зато је рад на овом делу обележен менталним проблемима, сломовима и хоспитализацијом.

Вулф почиње рад на роману Излет на пучину (1915) са великим ентузијазмом и жељом да га оконча што брже не би ли могла да истражује идеје које има за будућа дела. Тако се 1907. и 1908. спрема за писање, планира како ће спровести тај процес и концентрише се на интензиван рад на рукопису, извештавајући своје пријатеље да ће целу јесен 1908. провести за столом, „и мукотрпно радити у мраку“ (Harris 2013: 48). Ипак, њени ментални проблеми непрестано прекидају рад, каткад и на неколико недеља или месеци, толико да скоро целу 1910. годину није у могућности да пише, а у фебруару је напетост и немир доводе „опасно близу руба болести“, те, по препоруци лекара, више пута одлази из Лондона на село ради опоравка и одмора (Harris 2013: 48). Пошто пати од депресије и суицидних мисли, рад на рукопису је опушта и пружа утеху, али и чини раздражљивом и депресивном. Она је посвећена раду, али није у стању да изађе на крај са свакодневним обавезама и проблемима, и то је - уз мањак искуства и списатељске вештине - разлог зашто јој треба толико времена да оконча свој рукопис. Он је завршен у јулу 1913, али Вулф ни тада није сигурна да ће он бити публикован. Иако њен полубрат Џералд Дакворд обећава да ће објавити роман, он одлаже тај тренутак наредне две године, правдајући се лошим економским стањем, неизвесношћу њеног здравља и ратом (Лемасон 2008: 30), те роман стиже до читалаца тек крајем марта 1915, док ауторка неколико недеља пре тога доживљава свој најтежи слом, те је превише слаба да би прославила тај успех (Лемасон 2008: 31; Harris 2013: 58). Овај роман надјачава њену психичку равнотежу, али је дочекан са позитивном рецепцијом и охрабрујућим коментарима критике, читалаца и пријатеља (Лемасон 
2008: 31), што јој даје подстрек за опоравак. Вулф у овај роман уноси и део сопственог искуства - смрт брата Тобија која личи на смрт протагонисткиње Рејчел, ${ }^{2}$ на пример - и личних ставова, поигравајући се идејом властитог разоткривања и описујући жену која је „надомак брака, а онда је обузме грозница од које полуди“ (Harris 2013: 54). Живот главне јунакиње је ауторкин коментар о сопственом менталном стању, а ово дело је донекле и Bildungsroman, јер јунакиња пролази пут од девојке до жене, откривајући себе, свет и своје место у њему (Дојчиновић 2013: 410). Отуд је њен пут конкретан и апстрактан, физички и метафизички, а најава двострукости види се у наслову: ${ }^{3}$ слично наслову романа Ка светионику, насловна фраза крије алузију на пут до Јужне Америке, пут самооткривања и стасавања, али и на пут у смрт (Brewster 1963: 87; Lee 1977: 32).

Током тог путовања, Рејчел Винрејс доживеће трансформацију и значајне промене, дочекати смрт и видети најаву Првог светског рата. Овај догађај само је маргинално приказан у роману јер је рат у време писања дела тек претећа појава, а не конкретна опасност. Алузије на њега пружају разумевање односа енглеског друштва према појави рата - нарочито у контексту тврдње А. Џ. П. Тејлора да та земља више деценија није учествовала у ратовима и да стога ниједан одрастао мушкарац заправо не зна шта рат заиста представља (Taylor 1963: 22) - као и антиципацију његовог третмана у каснијим романима

2 Ауторкин брат Тоби умире од тифуса 1906, а тај губитак додатно слаби списатељицу која је већ изгубила родитеље, док његову смрт доживљава емотивно: „Тобијева смрт била је трагедија од које Вирџинија није могла лако да се опорави. Две године касније, и даље је акутно осећала тај губитак; било је необично живети у свету у којем њега није било, а чак двадесет година касније, њој се чинило да ни њен сопствени живот није ништа више но излет без њега, и да ће смрт бити прилика да се врати у његово окружење“ (Bell 1972: 112).

${ }^{3}$ Ауторка напушта првобитан наслов Melymbrosia - измишљена реч која спаја латинску и грчку реч за мед и амброзију - током једне од седам исправки, али Луиз де Салво, на основу њених белешки и рукописа, реконструише и објављује првобитну варијанту романа 1982. године (Lee 1977: 32; Дојчиновић 2013: 410). 
ауторке. Овде се у више наврата дискутује о стању британског друштва и целе империје, а ауторка предосећа да је та империја на издисају. Путници остављају „Лондон да лежи у блату“ (Вулф 2013: 26) и хрле у фиктивну јужноамеричку колонију, а Вулф их, и, пре но што рат почиње, шаље „на пловидбу преко расцепа британске империје“ (Немет 2015), док се њен став о сопственој држави највише види уласком брачног пара Даловеј у роман. Они се придружују „Еуфросини“ у Лисабону пошто, наводно, путују Европом, али се праве намере њиховог пута убрзо откривају: они не путују без циља, „углавном имајући у виду проширење видика госпође Даловеј“ (Вулф 2013: 39), већ ради испитивања „спољнополитичке ситуације и ратног кошкања које је већ започето у Европи“ (Немет 2015). Негативан однос јунака према њима - Вилоби Винрејс каже да су они „господин који сматра да због тога што је некад био члан Парламента“ и „племићка кћер“, особе које мисле да могу да имају шта год пожеле (Вулф 2013: 39) - само се интензивира и конкретизује након што се открива да они путују кроз Француску и Шпанију, проверавајући како живи обичан народ и испитујући да ли су спремни за побуну, на основу чега Даловеј предвиђа „кризу која ће брзо уследити“ (Вулф 2013: 39). Тек касније Клариса признаје да њихов пут кроз Шпанију није одмор, нити су они тамо случајно, и даје изјаве пуне патриотизма, ${ }^{4}$ које не наилазе на одобравање њихових сапутника, па ни читалаца, јер је јасна иронија са којом се ауторка опходи према овом слоју британског друштва. Све то читаоцима даје до знања да је сукоб у Европи близу, а ауторка предосећа рат и револуције, и, иако су алузије на те догађаје суптилне, свет јесте у превирању (Дојчиновић 2013: 415). Просторни отклон јунака од тог сукоба - они су прво на броду, а касније у Јужној Америци - не значи да ће побећи од судбине која их чека, а планови о

4 „Када си на овом броду, делује много сликовитије - шта стварно значи бити Енглез. Размишљаш о свему што смо урадили, о нашој морнарици и о људима у Индији и Африци, како вековима шаљемо момке из малих села - и о људима као што си ти, Дик, човеку се чини да не би могао да поднесе чињеницу да није Енглез! Замисли светло које гори изнад Парламента, Дик! Када сам малочас стала на палубу, учинило ми се да га видим.“ (Вулф 2013: 52). 
заједничком животу у Лондону које Рејчел и Теренс праве, не би се остварили ни да јунакиња не умире, управо зато што су „Британија и свет какав [они] знају - на издисају“ (Дојчиновић 2013: 415). Британска империја више није оно што је била, а њени грађани не осећају исти патриотизам: кад виде ратне бродове, једни су одушевљени, док други коментаришу о условима на њима. Клариса, рецимо, кличе („Ратни бродови, Дик! Тамо! Погледај!“) и истиче да ти бродови код Рејчел треба да пробуде патриотизам (,Зар ти није драго што си Енглескиња!“”) (Вулф 2013: 72), док тетка Хелен говори да јој „делује погрешно држати морнаре као када се држи зоолошки врт, и да је, када је реч о умирању на бојном пољу, свакако време да престанемо да славимо храброст“ (Вулф 2013: 72-73). Ова два супротстављена става најављује коментар приповедача о изгледу тих бродова - у питању су „два злокобна сива пловила, дубоко у води и гола попут кости, која су се кретала тик једно до другога, са изгледом слепих звери које траже свој плен“" (Вулф 2013: 72) - а њихов изглед предвиђа Рејчелину смрт и друге губитке који ће наступити током рата (Немет 2015). Ти бродови су гласници рата - слично као што је у роману Између чинова то случај са авионима (Дојчиновић 2013: 415) - и показатељи ратне спреме британске војске, коју Вулф још једном помиње у роману, опет у негативном светлу, истичући да би „летење било нужно у време рата, а ми у Енглеској страшно заостајемо“ (Вулф 2013: 143). Тако тема романа није само буђење свести Рејчел Винрејс, већ и буђење свести о близини рата и опасности која се конкретизовала у периоду између окончања и публиковања рукописа. Роман Излет на пучину је прво дело ауторке у којем се рат јавља, али је он сада тек најава и опасност на пучини, а већ у наредном роману постаје фактор који одређује судбину протагониста.

Након романа Ноћ и дан (1919), који читаоце враћа у прошлост, ${ }^{5}$ Вулф се у роману Џејкобова соба (1922) поново поиграва

5 Роман је писан током рата, док ауторка слуша „потмулу грмљавину топова коју је вјетар доносио из сјеверне Француске. Грмљавина смрти била је једва чујна, далека, тешко повезива с било чим из свакодневице“ (Harris 2013: 62). Она стога, уместо фронта, описује цивилни свет, покушавајући да пронађе 
са хронологијом и доводи поратни роман до нових граница својим експерименталним изразом и приступом који је истовремено и једноставан и интригантан. Он се базира на чињеници да је главни јунак, Џејкоб Фландерс, тек делимично у наративу и да информације које читаоци добијају о њему махом долазе од људи из његовог окружења. Тако он расте у протагонисту који је истовремено присутан и одсутан, а сам текст постаје потрага за њим. Она се, међутим, завршава неуспешно, пошто Џејкоб пред крај романа одлази у Први светски рат и гине, док читаоци не сведоче његовој смрти, већ о њој сазнају од његове мајке и пријатеља. Стога се никада не види „коначан, потпун портрет Џејкоба, али успијевамо га назријети у гомили или док чека у реду, а чујемо и људе који о њему разговарају“ (Harris 2013: 77-79). Овај поетички приступ се ауторки намеће случајно, почетком 1920. године, док размишља о савременој књижевности и експериментима које примењује у својој приповедној прози - највише у збирци Понедељак или уторак из 1921. године, али и другим текстовима - и она прво формулише стил и форму дела, а тек касније размишља о његовој примарној теми и јунацима (Lee 1977: 71). Ово искуство открива у дневнику крајем јануара и описује узбуђење при раду на новом рукопису у којем ,,једна ствар произилази из друге“, чиме се постиже проходност и свеобухватност текста (Вулф 2002: 29). Она пише роман од априла 1920. до новембра 1921, и мада је овај период кратак, он није написан стихијски, највише због припреме ауторке, њеног труда и искуство које уноси у њега (Harris 2013: 60). Вулф бележи како се осећа током и након писања романа, те реакције

било какав спокој и илузију сигурности (Outka 2016: 60, 64). Овакав приступ, међутим, изазива неразумевање читалаца, премда рат обликује наратив, изазивајући страх у Лондону, потрагу за уточиштем и дилему око чега се рат уопште води и да ли у свету постоји нешто вредно спасења (Outka 2016: 57; Briggs 2006: 43). Романи Ноћ и дан и Џејкобова соба нису преведени код нас, али су доступни на хрватском језику; видети: Woolf 2011; Woolf 2012. 
свог супруга Ленарда, својих пријатеља и критичара који дочекују роман са одобравањем, хвалећи стил и експериментални приступ. ${ }^{6}$

Овај роман је потребан ауторки као „неопходан корак ка слободном раду“ (Вулф 2002: 56), и стилски експеримент који води ка наредним делима. У питању је прича о одрастању јунака у коју се, уз мноштво елемената традиционалног биографског романа, уплићу и експериментални делови, те се заправо ради о роману у којем се „нижу тренуци скицирани с тек неколико упечатљивих реченица које опасавају празнине и елипсе“ (Harris 2013: 60). Читалац прати Џејкоба од детињства, преко студија на Кембриџу и живота у Лондону, све до путовања у Француску, Италију и Грчку, спајајући све тачке његовог животног пута који се окончава смрћу у рату. Последње поглавље доноси преокрет, и тако дело, сем експерименталне и фрагментарне биографије, постаје и елегија о протагонисти коју доноси „равнодушни, лирски глас [који] зазива предратни свијет, глас тек дијелом свијестан да држи посмрти говор“ (Harris 2013: 60, 79). ${ }^{7}$ Он расте у епитом генерације, показујући како је цео нараштај младића који је страдао у рату живео пре 1914, и антиципирајући шта су могли да постигну да су преживели (Hattaway 1993: 19; Holtby 1932: 116). Игноришући рат и не представљајући Џејкобову смрт директно, Вулф ствара анти-ратну књигу у којој рат није покретачка снага, већ инцидент који на најтрагичнији могући начин окончава живот протагонисте. Ипак, осећа се критика рата и негативан однос према њему, али и према „вредностима, историјским митовима и друштвеним илузијама које су довеле до рата“, те чињеници да се та генерација после рата осећа одсечена од прошлости и без правог упоришта, као Одисеј који се никада не враћа на Итаку (Mepham 1991: 78). Читалац једино може да закључи да је протагониста погинуо у рату, и то из

6 Литон Стрејчи, рецимо, истиче да је запањен ауторкином умешношћу да изостави ужас рата, али ипак наговести своју примарну тему (Brewster 1963: 100). Видети и: Вулф 2002: 33, 50-53.

7 Роман је, узгред, елегија за погинуле пријатеље ауторке, али и за Тобија, који је одсутан из њеног живота, слично као што је Џејкоб одсутан из текста (Lee 1977: 731; Hattaway 1993: 21). 
реакције његове мајке, и да види само исечке из његовог живота. Овакав приступ делимично настаје под утицајем Уликса Џејмса Џојса - тај роман излази исте године, а Вулф га чита у рукопису и, заједно са Ленардом, одбија да га публикује (в. Вулф 2002: 51-52, 53-54) посебно на плану флуидности, фокализације, избегавању уобичајених тропа тадашње књижевности и технике тока свести (Daiches 1942: 5354, 57-58). Сем што донекле баштини Џојса, роман Џејкобова соба доноси мноштво стилских, наративних и поетичких иновација, тражећи нову форму којом ће представити Први светски рат.

Ту формулу Вулф проналази у одсуству главног јунака који као да не учествује у радњи, или бар не у очекиваној мери. Џејкобов живот је ,збир тренутака које нам писац саопштава као значајне, а који, међутим, нису и најважнији“ (Натан 1964: 137), док читаоци не сазнају ништа конкретно јер је све што га одређује као особу прећутано. Он остаје обрис јунака „као одраз у свести других јунака, као уверљиво упозорење на чињеницу да смо пречесто одсутни из оног што би требало да буде наш живот, и да нам тај живот [...] измиче, пролази мимо нас док правимо друге планове“ (Пауновић 2017: 81). Џејкоб је представник свих погинулих младића и оних који чине предратне године безбрижнима и упечатљивима, а његово понашање типично је за младиће његове генерације и само доказује обим колективне трагедије која се десила неколико година касније. Да се рат није десио, или да Џејкоб није учествовао у њему, његов живот, и сам роман, оставили би потпуно другачији утисак на читаоце. Ипак, присуство рата је неизбежно у животу ауторке, и стога она не може да заобиђе ту тему. Рат је пресудни тренутак романа и Џејкобовог живота, кулминирајући његов животни пут и дефинишући дело на нов и упечатљив начин, као истовремено и ратни и анти-ратни роман (Sherry 2016: 74). Ауторка се не посвећује погибији протагонисте, и открива је на тек две странице последњег поглавља, нагло заустављајући причу о Џејкобу, доказујући све нагле прекиде живота свих учесника рата, али и оних који их чекају у домовини. Ипак, када се роман поново прочита са знањем о крају, примећује се велик број алузија на ратно стање и смрт уопште, и ти суптилни трагови расту у антиципацију Џејкобове погибије. Романом провејавају алузије на претходне ратове (од Тројанског до Битке код Ватерлоа, укључујући отворене асоцијације 
на град Скарборо), ${ }^{8}$ док је Џејкоб на почетку романа окружен животињским лешевима, мољцима и костима, а његовој мајци се на крају претпоследњег поглавља чини да чује буку топова, предосећајући смрт сина. Сви ови елементи граде специфичну атмосферу у роману која „као да од почетка наговјештава трагичан крај главног јунака“ (Летић 2017: 87), али ниједна од ових назнака трагедије није претерано очигледна. Ауторка овде, за разлику од романа Госпођа Даловеј или Године, представља рат суптилно и скривено, не као разарајућу силу која уништава све пред собом, већ као догађај који је негде у близини јунака и чека тренутак да им се прикраде. Њену суптилност означава и карактеризација протагонисте, односно његово презиме Фландерс, симболички набијено алузијама на Фландрију, толико да постаје више од презимена и расте у слутњу трагедије и поистовећује се са траумом и губицима целог друштва (Летић 2017: 87-88; Zwerdling 1986: 64; Correia 2014: 239). Џејкобово презиме га чини савршеним епитомом ратне генерације - он је толико неприсутан у роману и достиже нови ниво анонимности да се чак и његов идентитет поистовећује више са ратом него са њим као личношћу (Reichman 2016: 242). Њега у роману не проналазе ни читаоци ни приповедач, те последња сцена, у којој мајка у његовој соби држи његове ципеле, показује да он нестаје из дела као да никада није ни живео. Иако Вулф помиње почетак Првог светског рата и алудира на одређене догађаје из његових првих месеци - пита се где су нестали сви мушкарци, помиње како је европске градове прекрила тама и описује Версај - она инсистира на трагедији једног човека уместо на колективном ламенту о генерацији. Но, и тај приступ довољан је да читаоци осете мрачну атмосферу дела и поистовете Џејкоба Фландерса са свим осталим младићима његовог нараштаја.

8 То место су у децембру 1914. године торпедирали немачки бродови, а помињање тог локалитета подсећа читаоце на ратна страдања, усмеравајући им пажњу на рат и антиципирајући тематизацију романа (Briggs 2006: 196). Такође, једанаесто поглавље помиње Версај, асоцирајући на потписивање Версајског споразума 28. јуна 1919, чиме је и окончан Први светски рат (Sherry 2016: 67). 
Последње поглавље романа разликује се од претходних на стилском, значењском, тематском и језичком плану, па би се могло читати одвојено од остатка рукописа, али, чак и да се то деси, он не би изгубио трагици и упечатљивости. Од изненађења Џејкобовог пријатеља Ричарда - „,Све је оставио управо како је било. [...] Ништа није поспремљено. Сва његова писма поразбацана су тако да их сватко може читати. Што је очекивао? Је ли мислио да ће се вратити?“ (Woolf 2011: 222) - до туге његове мајке Бети која у рукама држи синовљеве ципеле, ово поглавље је крајњи доказ одсуства протагонисте. Стил који Вулф користи започет је у њеној краткој прози и заснива се на редукцији израза и потенцирање оног што се прећуткује. Уместо да детаљно опише Џејкобову смрт и реакцију његове мајке и најбољег пријатеља, она им даје тек неколико реплика које су ипак довољне да пренесу ефекат који његова смрт оставља. Ауторка не описује већ само скицира ту смрт, дајући читаоцима активнију улогу и тражећи од њих да самостално интерпретативно допуне текст и закључе шта се јунаку десило. Тако она доказује идеју да се о рату не мора писати обимно и детаљно, већ да је довољно нагласити детаљ или два, али овакав стилски приступ показује и колико је језик који се користи након рата неадекватан да опише све шта се дешава преживелима и пренесе сва сећања и утиске преживелих (Sherry 2016: 68, 74). Тај језик не може да адекватно дочара ратну и поратну стварност, и стога га ауторка не користи, више скицирајући протагонисту него га описујући, и посветивши се прећутаном више но исказаном. Њен приступ рату је у исти мах сиров и апстрактан (Cole 2016: 336), и зато се роман Цејкобова соба данас препознаје као прекретница у опусу ове списатељице и дело које развија нови начин мишљења и писања, покренувши најпродуктивнији и најкреативнији период њеног рада (Mepham 1991: 84). Уз то, он доказује моћ прећутаног и наговештеног у односу на конкретно и директно, што ауторка касније често истражује у својим романима и приповеткама. ${ }^{9}$

${ }^{9}$ Приповетке су битан део ауторкиног опуса, али је присуство рата у њима блаже и суптилније. Прва приповетке, написане током Првог светског рата, промишљају савремене догађаје и став да је историја изгубљена, а одликују 
Након овог романа, Вулф се посвећује авантурама Кларисе Даловеј и неколико година касније стиже до свог најпознатијег наслова, романа Госпођа Даловеј (1925). Одјеци Првог светског рата у њему су огромни, од послератне атмосфере која се осећа на лондонским улицама, преко тмурних сећања грађана у чијој свести су ратни догађаји још увек живи, све до лика Септимуса Смита, повратника из рата и једног од најуспелијих јунака обележених ратом не само у прози ове списатељице, већ и у прози целе генерације којој она припада. У каснијим делима попут романа Ка светионику (1931) и Године (1937), ауторка сумира ратно искуство свог нараштаја и целог друштва, додајући нове слојеве на колективно ратно сећање и рекапитулирајући га. Имајући у виду да романескни опус ове ауторке чини девет дела, а да је Први светски рат значајан део пет наслова, јасно је да је овај историјски догађај битан елемент њеног целокупног стваралаштва. Чак и кад не описује ратне незгоде и последице директно, она алудира на њих, и „сви су њени поратни романи заокупљени неизравним начинима на које се миримо са својим губицима“ (Harris 2013: 62). Занимљиво је, пак, пратити начин на који тематизација рата еволуира у њеним романима - од предвиђања до рекапитулације, овај развојни пут показује промене у стилу ауторке и њеном погледу на свет и књижевност, те како тема рата јача и слаби у енглеском друштву током двадесетих и тридесетих година. Стога се и тематизација рата у опусу списатељице може поделити на два дела пре и после романа Госпођа Даловеј - при чему први део корпуса чине романи Излет на пучину и Џејкобова соба, у којима је рат у најави или траговима, а други Ка светионику и Године, који конкретно говоре о рату и последицама. Због тога су прва два поменута романа нарочито значајна јер се ради о мање познатим и ређе анализираним делима ове

их техника сажимања и економични дијалози. Друга група приповедака, написаних у најплоднијем периоду креативног рада, између 1917. и 1925, представљају експерименте у форми, стилу и нарацији које Вулф користи у каснијим романима. Трагове рата могуће је, ипак, наћи у приповеткама „Ненаписана новела“, „Жичани квартет“, „Краљевски врт“, „Знак на зиду“, „Рефлектор“ и „Једно друштво“. Видети: Skrbic 2004: хx; Marcus 2016: 31; Sherry 2016: 68; Dick 1985: 3; Ђурић-Пауновић и Стевановић 2011. 
ауторке који ипак крију висок квалитет и вредност. ${ }^{10} \mathrm{y}$ њима се тај пресудан историјски догађај анализира на суптилнији и скривенији начин, али ипак довољно снажно да наговесте све последице Првог светског рата и најаве његов третман у каснијој прози Вирџиније Вулф.

\section{ЛИТЕРАТУРА}

Bell, Quentin. 1972. Virginia Woolf: A Biography. New York: Harcourt Brace Jovanovich, Inc.

Brewster, Dorothy. 1963. Virginia Woolf. London: George Allen \& Unwin. Briggs, Julia. 2006. Reading Virginia Woolf. Edinburgh: Edinburgh University Press.

Вулф, Вирџинија. 2013. Излет на пучину, превео Лазар Мацура. Београд: Службени гласник.

Вулф, Вирџинија. 2002. Дневник списатељище, изводе из дневника приредио Ленард Вулф, превела Славица Стојановић, редактура превода Драгана Старчевић. Београд: Феминистичка 94.

Daiches, David. 1942. Virginia Woolf. Norfolk: New Directions Books.

Dick, Susan. 1985. "Introduction". Woolf, Virginia. The Complete Shorter Fiction of Virginia Woolf. San Diego: Harcourt Brace Jovanovich.

Дојчиновић, Биљана. 2013. „Излет у срце модернизма“. Вулф, Вирџинија. Излет на пучину, превео Лазар Мацура. Београд: Службени гласник: 409-440.

Ђурић-Пауновић, Ивана, Стевановић, Кристина. 2011. „Освајање текстом: кратке прозе Исидоре Секулић и Вирџиније Вулф“. Бошковић, Д. ур. Српски језик, књижевност, уметност: зборник радова са V међународног научног скупа одржаног на Филолошко-уметничком факултету у Крагујевиу, (29-30. Х 2010). Кн. 2, Жене: род, идентитет, књижевност. Крагујевац: Филолошко-уметнички факултет: 181-198.

\footnotetext{
${ }^{10}$ Критика истиче да Вулф тек након Госпође Даловеј добија статус успешне списатељице (Strode 1941), док Раит наводи студије које игноришу прве романе, фокусирајући се на касније (Raitt 2010: 29, 45ф1).
} 
Zwerdling, Alex. 1986. Virginia Woolf and the Real World. Berkeley: University of California Press.

Lee, Hermione. 1977. The Novels of Virginia Woolf. London: Methuen and Co.

Лемасон, Александра. 2008. Вириинија Вулф, превела Драгана Банковић. Београд: Clio.

Летић, Марија. 2017. Стварање и идентитет: сумрак свијести у романима Вирииније Вулф. Источно Сарајево: Филозофски факултет.

Marcus, Laura. 2016. "The Short Fiction”. Berman, J. ed. A Companion to Virginia Woolf. Oxford: Wiley Blackwell: 27-39.

Mepham, John. 1991. Virginia Woolf: A Literary Life. London: Macmillian Press.

Натан, Моник. 1964. Вириинија Вулф: њом самом, превела Јелена Јелић. Београд: Савремена школа.

Немет, Софија. 2015. „Тема рата у романима Излет на пучину и Госпођа Даловеј Вирџиније Вулф“. Книженство, 5 (5).

Outka, Elizabeth. 2016. "The Transitory Space of Night and Day". Berman, J. ed. A Companion to Virginia Woolf. Oxford: Wiley Blackwell: $55-66$.

Пауновић, Зоран. 2017. „Живот је негде другде“. Прозор у двориште. Београд: Геопоетика издаваштво, 79-83.

Raitt, Suzanne. 2010. "Virginia Woolf's Early Novels: Finding a Voice". Sellers, S. ed. The Cambridge Companion to Virginia Woolf. Cambridge: Cambridge University Press: 29-48.

Reichman, Ravit. 2016. "Woolf and the Law". Berman, J. ed. A Companion to Virginia Woolf. Oxford: Wiley Blackwell: 235-247.

Skrbic, Nena. 2004. Wild Outbursts of Freedom: Reading Virginia Woolf's Short Fiction. Westport: Praeger Publishers.

Sherry, Vincent. 2016. “Jacob's Room: Occasions of War, Representations of History". Berman, J. ed. A Companion to Virginia Woolf. Oxford: Wiley Blackwell: 67-78.

Strode, Hudson. "The Genius of Virginia Woolf". http://movies2.nytimes.com/books/97/06/08/reviews/woolfacts.html (29.20.2019)

Taylor, A. J. P. 1963. The First World War, an Illustrated History. London: Hamish Hamilton. 
Harris, Alexandra. 2013. Virginia Woolf: biografija, preveo Slaven Crnić. Zagreb: Sandorf.

Hattaway, Judith. 1993. "Virginia Woolf's Jacob's Room: History and Memory". Goldman, D. ed. Women and World War 1: The Written Response. London: Macmillan: 14-30.

Holtby, Winifred. 1932. Virginia Woolf. London: Wishart.

Correia, Marta. 2014. "People are Ghosts: World War I in Virginia Woolf's Jacob's Room (1922) and Mrs Dalloway (1925)". Cadernos de Literatura Comparada (31): 237-248.

Cole, Sarah. 2016. "Woolf, War, Violence, History, and ... Peace". Berman, J. ed. A Companion to Virginia Woolf. Oxford: Wiley Blackwell: 333-345.

Woolf, Virginia. 2011. Jakobova soba, prevela Marina Leustek. Zagreb: Centar za ženske studije.

Woolf, Virginia. 2012. Noć i dan, preveo Lovro Škopljanac. Zagreb: Centar za ženske studije.

Dragan Babić

\section{ANTICIPATION AND EFFECT OF THE FIRST WORLD WAR IN VIRGINIA WOOLF'S NOVELS THE VOYAGE OUT AND JACOB'S ROOM}

\section{Summary}

ABSTRACT: When investigating Virginia Woolf's work, most scholars and readers stick to a handful of titles: novels Mrs Dalloway, To the Lighthouse, and The Waves, as well as her book-length essays A Room of One's Own and Three Guineas. While this is absolutely understandable, due to the quality of these works, it is not completely fair. When looking deeper into the body of work by this author, we can find several other titles that deserve our attention, including The Voyage Out and Jacob's Room, her first and third novel. The importance of these novels goes beyond the anticipation factor - because they do in fact anticipate Mrs Dalloway, The Waves, and other prose this author wrote after them - and is concerned with the treatment of the First World War in them. Namely, even though this event is very important in Woolf's life and work, it is not central in these novels. They were published during and after the War - in 1915 and 1922, respectively - and feature characters that are involved in it and affected by it, but they do not address them in an obvious and open way. Instead, they foreshadow the War and its effects using 
several different narrative and stylistic techniques, and this paper will try to explain these techniques and their importance.

Keywords: Virginia Woolf, The Voyage Out, Jacob's Room, First World War, anticipation 